\title{
Dividing the Oils: Dynamic Bargaining as Policy Formation in the Nigerian Petroleum Industry
}

\author{
Laura Hosman \\ Illinois Institute of Technology
}

\begin{abstract}
In academic studies of the interface between developing countries and large multinational oil corporations, scholars have noted that over time and through repeated interaction, the developing countries tend to negotiate better outcomes for themselves: they progress along a learning curve by incrementally improving their outcomes through bargaining and strategic interaction. This phenomenon can be demonstrated in a number of oil-rich developing countries. Nigeria's case, however, is more complex. During the two decades following its independence, the state successfully negotiated for more control over-made strides in the developing of the skills necessary to manage-its petroleum industry, as our model would predict. Then, in a puzzling late-1970s-to-mid-1980s change of course, the government abruptly gave back concessions, undermined local entrepreneurial endeavors, and repealed indigenization laws. This paper combines, in the analytic narrative tradition, the case study method with an extensive form game; it applies a dynamic bargaining model to Nigeria's historical experience, demonstrating that Nigeria improved its outcomes and ascended along the "bargaining learning curve," only to reverse policy and "unlearn," with serious consequences for the Nigerian population. Even so, the demonstration of both successful and improved outcomes in past negotiations give evidence that Nigeria could once again ascend its bargaining learning curve if the government were to re-commit to such a policy.
\end{abstract}

KEY WORDS: natural resources, dynamic bargaining, learning curve, petroleum, Nigeria

\section{Introduction}

$T_{1}$ he past 40 years have seen much written about multinational corporations' (MNCs') investments in developing countries, particularly in the area of nonrenewable resource extraction. This scholarly interest coincides with an exponential increase in such investments and often focuses upon either the exploitative nature of said relationships or the phenomenon known as the resource curse: a skewed economy in which the state allows a single industry to dominate to the detriment of all others.

However, a small number of researchers have taken up this subject with an eye to understanding how resource-rich developing countries can do better for themselves within the context of their relationships with MNCs (Moran, 1974; Smith \& Wells, 1975; Vernon, 1971). The intent of this article is to build upon their work, focusing its analysis on this bargaining interface-giving particular attention to Nigeria's experience-exploring historical policy decisions made within the context of negotiations over oil concessions, and analyzing the outcomes and resulting effects on the Nigerian population.

The framework for analysis is that of analytic narrative, or historical case description, combined with rational-choice methodology (Bates et al., 1998). The article presents Moran's dynamic bargaining model as a lens through which the negotiations may be viewed. The principal argument put forth is that Nigeria initially ascended its bargaining learning curve; this is demonstrated through an extensive 
form game that focuses on the dynamic bargaining between representatives of the Nigerian government and Multinational Oil Corporations that took place mainly between 1971-79.

However, after this period the state abruptly reversed course. Numerous policy decisions were made that first, gave back hard-won concessions to corporations, and second, repealed indigenization laws and forcibly deterred local participation in Nigeria's oil industry. Through these actions, the state descended its own learning curve, with serious consequences for its population that remain up to the present. Although not the central focus of this article, an argument will be presented that posits that corruption likely played a determining role in the implementation of these otherwise puzzling policy decisions. Even so, the demonstration of both successful and improved outcomes in the negotiations that took place in the past give evidence that Nigeria could once again ascend on its bargaining learning curve if the political will exists to promote policies focused on long-term gains that would benefit the greater population rather than short-term gains directed to the advantage of an elite few. Given the scope of this article, the subsequent issue of what the state does with the increased (or decreased) share of the pie that it obtains through bargaining will remain for future research.

The article proceeds as follows: The dynamic bargaining model that serves as the framework for understanding bargaining policy decisions is presented. This is followed by an overview of game theory, dynamic bargaining, and Bayesian equilibrium analysis. Next is the case study of Nigeria: a historical overview of the bargaining policy decisions made by the Nigerian government is presented and, subsequently, modeled in an extensive-form game. Following this, the policy decision reversal that led to a "descent" on Nigeria's learning curve is described. The article concludes with a discussion of the ramifications that these policy decisions have had up to the present day for Nigeria's population, the government's financial state of affairs, and the eventual (in)ability of the indigenous populations to develop the monitoring, operating, and supervisory skills necessary to reduce dependence on the corporations.

\section{The Dynamic Bargaining Model}

Multinational extractive corporations must, in their search for unexploited resources, negotiate with the governments of the developing countries in which such resources are generally found. As such, states seldom have an established legal framework for these relationships and individual contracts must be negotiated. Yet because they are designed to cover all aspects related to a nascent yet complex industry, the contracts are often less than ideal and need to be altered over time, as conditions change.

At the outset, the two actors enter into negotiations in widely divergent situations. The MNC has monopolistic control over the technology necessary to develop the natural resource in question. It also possesses a great deal of business and negotiation acumen in the form of large legal teams experienced in the process in general and, specifically, as it relates to oil. Conversely, the developing country possesses neither bargaining experience nor expertise relevant to the development of an oil industry. 
With such a seemingly insurmountable inequity in place, many were surprised when, in the 1970s, academic observation of the historical record of MNCs' and developing countries' interaction found that over time, agreements between the two actors tended to become increasingly favorable to the developing country (Mikesell, 1971; Moran, 1974; Smith \& Wells, 1975).

Theodore Moran studied the Chilean copper industry and formulated a testable hypothesis to explain this phenomenon; the resulting theory came to be known as the dynamic bargaining model. Moran writes of a learning curve for developing countries: over time they gain experience in bargaining and business and become better negotiators. Negotiation and strategic interaction incrementally improve their outcomes; they form contracts more favorable to their side-Moran (1974) calls this "ascending the bargaining learning curve." As the states gain experience and confidence, they take steps to ensure that their indigenous populations develop the technical and management skills necessary to manage the industries without dependence on the corporations.

Successful ventures ... provide an incentive for the host country to develop skills and expertise appropriate to the industry. Beginning with elementary attempts to tighten the bargaining process, the country starts to move up a learning curve that leads from monitoring industry behavior to replicating complicated corporate functions. (Moran, 1974, p. 1)

This article is concerned with the application of Moran's theory to a case study of Nigeria in which the state's historical experience in developing its oil industry and doing business and negotiating with large MNCs is examined. Moran's theory builds on the Obsolescing Bargain Model developed by Raymond Vernon (1980), ${ }^{1}$ which states that when a bargain is struck and a corporation makes its initial investments, the bargaining position between it and the government involved immediately begins to change. The promise of investment is no longer a bargaining chip for the corporation and it finds itself with incentives to stay in the country: to avoid losing sunk costs and to reap the financial rewards envisioned in its profit projections. As soon as the initial investment-associated risks have disappeared and the corporation begins to realize a profit-in the case of petroleum, often a windfall-the host country starts to question the benefit distribution profile of the original contract. In retrospect, such agreements "invariably have the appearance... of the strong (company) cheating the weak (country)" (Moran, 1974, p. 160); this results in a developing country calling for contract renegotiations.

Scholars of concession arrangements traditionally viewed these contracts as a one-time bargain reflecting a win/loss relationship between the two negotiating parties. In the 1970s this position began to change; Smith and Wells (1975) and Moran (1974) argued that this notion was unrealistic given the numerous renegotiations and even expropriations in the world oil industry during the 1960s. The "win/loss" viewpoint ignored changes occurring-both within the industry and the host country - that shift the relative strength of bargaining positions over time; these changes are ultimately reflected in the nature of the contracts. In addition, by portraying bargains as zero-sum games, the stark scenario employed within static analysis did not accurately reflect reality. In fact, contract negotiations allow both 
sides to realize a mutuality of interests, employing a non-zero sum perspective in which bargaining determines the division of rewards-the collective "pie"between the two players. Thus, both may benefit.

Smith and Wells (1975, p. 246) directed future researchers to take into account economic, social, and political forces at work in the host country, the MNCs' interests and position in the global industry, and the dynamics of the industry itself when analyzing contract negotiations. They lamented the fact that game theory (in the 1970s) did not offer a model sufficient for a more dynamic view.

The ensuing 35 years, however, have seen considerable advances in the noncooperative, dynamic, and iterated areas of game theory methodology and application-the areas specifically applicable to bargaining theory. Morrow (1994, p. 3) argues that game theory now provides a tool for all social scientists: formal developments have pushed the methodology in ways unimaginable at first. He further asserts that it should be employed as a primary method of addressing the substantive issues that have arisen in the intervening years.

McKern (1993) points out —on a related note-that host countries have shifted their bargaining priorities from a focus solely on fiscal benefits toward a more complex schedule of needs and desires designed to realize both direct and indirect benefits. The application of a more descriptive, extensive form of game is thus a better fit in this case; a reduced mathematical methodology can be insufficient to an understanding of the entire range of the actors' concerns-which can include political and social considerations far beyond those mathematically measurable.

The need for a methodology that allows for more complexity follows logically from the increasingly multifarious nature of negotiations between developing countries and MNCs (McKern, 1993, p. 245). Host countries have moved, over time, from naively viewing MNC royalty payments as a "windfall reward" to a position of experienced negotiators dealing competently with taxation, ownership, and management, as well as with employment, environmental, infrastructural, investment, technology, and local economy concerns, among others (Moran, 1974, pp. 163-64). As some of these issues are more difficult to measure quantitatively than others, a descriptive methodology that underscores the continued need for the case study is necessary. This is a point on which all of the scholars mentioned earlier would agree: they all have employed case studies in their research.

And yet it is important that research does not stop at the case-study level. Qualitative and quantitative methods complement each other and ultimately must be combined (Odell, 2001). Herein is presented a framework for a systematic, game theoretic analysis of the MNC-developing country bargaining interface, one that can be-and has been-applied across relevant cases in conjunction with an in-depth descriptive historical analysis (Hosman, 2009), thereby combining qualitative and quantitative methods.

Back to Moran's theory: As previously stated, negotiations between the host country and the oil corporation are no longer viewed as a one-time occurrence. By taking strategic initiatives, the developing country seeks to strengthen its bargaining position in various ways over time. These initiatives may include a more thorough learning about the oil industry in general and the status of the achievements of 
nations in similar situations. A state enterprise may be established to monitor, supervise, manage, and eventually operate some or all of the industry involved. Training programs may be established to further this last goal by creating a skilled, indigenous workforce. It can be negotiated that this workforce be employed by the MNCs, that products purchased by the corporations be locally produced, and that equipment imported by the MNC becomes the property of the state upon its arrival. Further, the state may negotiate an increased level of equity in the contract or for a share of the final product.

This is not-nor is it meant to be-an exhaustive list of negotiable points; each country must decide what is best for its development path. Yet each issue represents a possible learning component on the part of the developing country. Each successfully negotiated concession chips away at the MNCs' monopoly of information and control; cumulatively, they shift the relative bargaining strength toward the host country (Moran, 1974, p. 165).

A principle criticism of Moran's theory is that it fails to account for the MNCs' corresponding learning curve: by treating the MNC as an exogenous variable in the bargaining interface, it is considered to be a constant, with only the state allowed to change, improve, and learn. Although initially considered, giving equal consideration to the MNCs' bargaining experience proved to be beyond the scope of this article: the description of negotiations would have been twice as complex and lengthy and its focus on developing countries sacrificed.

Nor does this analysis present a comprehensive list of all the players potentially affecting the bargaining scenario. There are, in fact, many possible actors that could affect the contractual decision-making process: the multinational's home country, competing MNCs, the developing country's state oil enterprise, and nongovernmental organizations or other interest groups. To maintain a suitably tight focus and provide for manageable games, this article has narrowed the number of actors examined to two.

As such, contract negotiations between the MNC and the developing country are characterized as strategic interactions between two actors seeking a mutually acceptable arrangement while each attempts to maximize its own profit. This situation is sufficiently generalizable as to allow analysis through the methodology of game theory, the subject to which we now turn.

\section{Game Theory and Bayesian Equilibrium Analysis}

Given the preceding characterization of contract negotiations between MNCs and developing countries, when such contracts are negotiated the interface conforms to the essential tenets of game theory. The bargaining is strategic; this means that the bargaining position of each actor at each decision point is a function of the perceived strategic preferences of the other player. The perceptions of these preferences are modified through a learning process. This updating of beliefs and strategies in response to the other actor's moves is known as Bayesian equilibrium analysis.

The game with which this paper is concerned is an example of international bargaining. According to Morrow (1994), interactions such as this should not be viewed as games of chance or games against nature with given, static probabilities. 
Instead, the negotiation process is better characterized as each actor making strategic decisions while uncertain about the behavior of the other. The probability assessment of each is shaped by a perception of the other's preferences and possible responses. As such, probabilities are subjective and subject to change.

The game is extensive in form. Players-each is seen as a unified entity-are faced with dual choices at each decision node. While clearly simplifications of reality, these assumptions are not to be seen as methodological liabilities; game theory's strength lies not in accurate description but in generalization. It is this ability to reduce a complex strategic interaction to a form applicable to other, similar situations and, by so doing, foretell behavior that is valuable to the academic process (Morrow, 1994, p. 1).

The strategizing, recalculating process of a bargaining game may be described as each actor identifying the available negotiating outcomes, ranking them to establish his preference ordering, formulating an assessment of his opponent's perceived preferences, and using this assessment to predict his opponent's likely bargaining strategies.

Previous interactions with, or the historical reputation of, the opposing player may color a player's perceptions. However, the absence of previous interaction-or one of the actor's lack of experience in the industry or bargaining scenario-may create a wide margin of error in probability calculation. It is important that strategic recalculation and probability reassessment is possible after the actor better understands the game and his or her opponent. An actor's preferences are revealed by his or her moves; each is able to readjust or reassess his or her strategy based on a refined perception of his or her counterpart's preferences. Bayesian equilibrium analysis is characterized by this possibility for readjustment of beliefs in response to observed events; this allows for the concept of learning during the bargaining process.

Collaborative effort can increase the size of the pie to be divided-and the absolute returns to each party-in the bargaining scenario at hand. Another of Moran's charts clearly illustrates this concept (Figure 1).

Game theory analyzes all possible strategies for each actor involved; as such, developing countries can gain significant insight into their own behavior and strategies and become more efficient bargainers. If a rigorous methodology is applied to the mapping out of its strategic interactions, a developing country can proceed more quickly along its learning curve or along a steeper curve, as illustrated by Moran's graph (Figure 2).

Logic, not complex mathematics, forms the core of the game presented in this paper; the extensive form was chosen to increase the game's applicability across multiple situations. The intent was to provide a methodological framework for systematic analysis of the negotiation process, within the context of Moran's learning curve concept and, by so doing, examine Moran's assertion that developing countries learn by doing and that game theory offers a method by which developing countries can systematize and better understand the bargaining process, learn to be efficient bargainers, and ascend the learning curve at an accelerated rate. The resulting game is applicable to the systematic analysis of bargaining between other developing country governments and MNCs. 


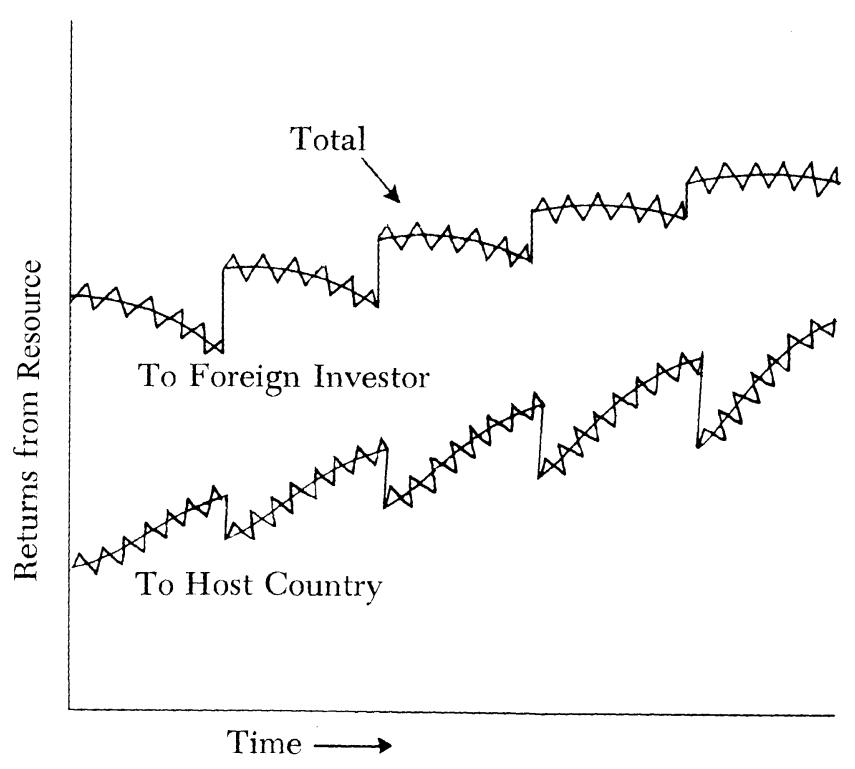

Figure 1. Moran's Learning Curve Illustrating Total Returns to the Foreign Investor and the Host Country. Source: Moran (1974, p. 162).

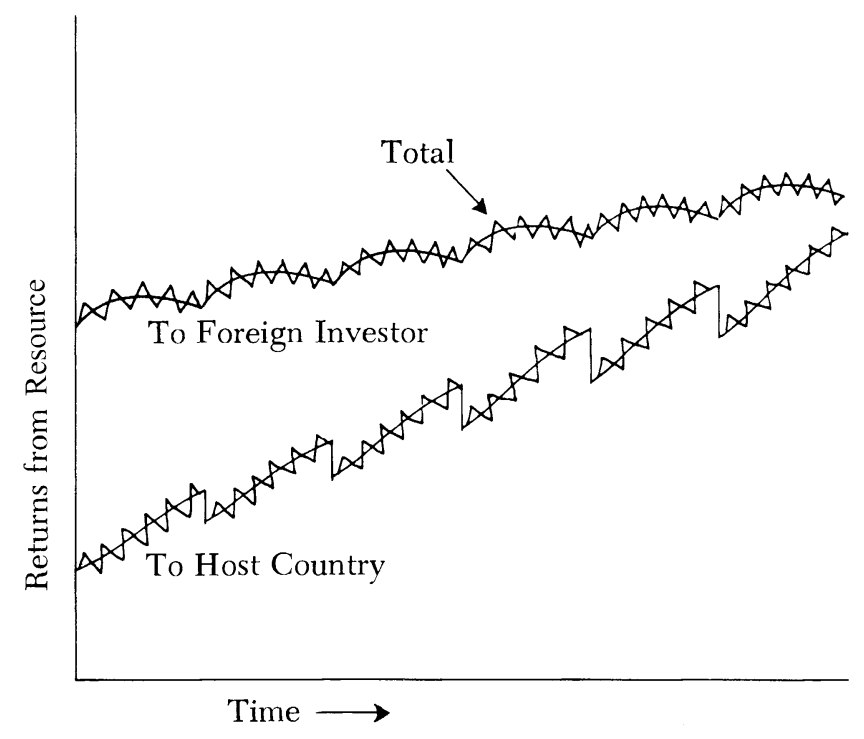

Figure 2. Moran's Accelerated Learning Curve.

Source: Moran (1974, p. 167).

\section{Case Study: Nigeria}

Since its independence from colonial rule in 1960, the Nigerian government has focused on, and become increasingly dependent on, its oil industry for revenues. Also since that time, Nigeria's oil industry has been characterized by the dominance of large foreign corporations. Even so, Nigeria has realized a degree of success in its dealings with oil multinationals, steadily improving its position through negotiation, at least for the first two decades following independence. 
However, the argument will also be made that Nigeria could have been more successful in its endeavors. This is because Nigeria has failed to fulfill the more advanced stages of learning defined in Moran's theory (the development of monitoring, supervising, and operating skills to increase control over its oil industry). In the event, Nigeria did advance on its bargaining learning curve, as will be demonstrated, but then the state took measures to give back the negotiated concessions. Instead of continuing to promote indigenous capacities to monitor, supervise, and operate its oil industry, Nigeria reversed course and actively prevented local participation in nearly all areas of the industry. As it stands, Nigeria's oil industry is controlled and run, de facto, by multinational oil companies (Asante, 1981; Atsegbua, 1992; Biersteker, 1980, 1987).

\section{Historical Overview of Nigeria's Bargaining Policy Decisions in the Petroleum Industry}

In 1938, while Nigeria was still under British rule, the colonial government granted a nationwide monopoly oil exploration license (OEL) to the British and Dutch government-owned company Royal Dutch Shell and British Petroleum. This company, which later became the Shell-BP Petroleum Company, retained its monopoly control of Nigeria's oil up until nearly the end of the colonial period.

Shell-BP made Nigeria's first commercially viable oil discovery in 1956 and began exportation in 1958. International interest in Nigeria's oil subsequently surged. Also in 1958, in the zeitgeist of the approaching end to colonial rule, the government repealed a section of the 1914 Mineral Oils Ordinance, allowing non-British companies the right to explore for oil in Nigeria.

As a result, Nigeria began granting OELs to a number of foreign oil companies even before its independence in 1960. However, the legislation governing these new concessions remained the Mineral Oils Ordinance of 1914, a vestige of colonial rule.

The concessions granted by Nigeria to foreign oil companies at this time were full concessions: they granted across-the-board power to the oil companies for the entire range of petroleum activities. Nigeria received no compensation other than royalty payments (United Nations [UN], 1982). The concessions were also lengthy in duration: those agreed upon during colonial rule ranged from 50 to 100 years.

Asante (1981) paints a bleak picture of concessions granted under colonial rule:

In many cases the companies paid a nominal rent of, say, 150 Naira for a whole concession, plus one or two bottles of rum. There was no royalty in the modern sense, that is, a fixed percentage of the gross proceeds of the resources. What purported to be a royalty-and this was a subsequent addition-was a provision for the payment of a minute percentage, say three to five percent of the declared profits of the companies. (p. 25)

Of course, without the business, pricing, or technical knowledge that the MNCs possessed, Nigeria had no way to verify declared company profits.

Following independence, the situation began to change, but Nigeria was not yet ready for direct negotiations with the oil companies, nor was it ready to participate actively in the development of its industry. In fact, in 1962, when the Italian-based MNC Agip Oil offered the Nigerian government the option to acquire a 30-percent equity share in its subsidiary company if commercial production of oil was attained, 
the Nigerian government-unprepared to venture into the unknown-turned down the offer (Asidou, 1979, quoted in Onyeji, 1990). Similar offers of equity interest in operations were made to Nigeria by both Shell-BP and Texaco, but because it lacked technical experience and bargaining skills, the government felt it safer to continue merely collecting rents on its oil.

In the early years of independence, some of the advances Nigeria made with respect to the major oil companies involved the collection of royalties. The royalty system was revised to include a nominal rent payment for the use of land, an excise profit tax, an import duties tax, and a small percentage tax on each barrel of oil that was sold. This tax was based on the price that the oil company declared it had received on the world market (which, again, Nigeria had no way to verify). Additionally, the concession periods were shortened in length, from 50-100 years to 40 years (with the option for the lessee to renew for a further period of 40 years). They subsequently were shortened to 20 years, and later on, in some cases, to five.

Despite these advances, Nigeria was still extremely dependent on foreign-based oil corporations to develop and run the industry and had little control over these corporations or, indeed, over the amount of revenues it could collect from them. However, it is important to point out that this situation of nearly complete dependence on the oil multinationals during the 1960s was common to virtually all developing countries that possessed oil, many of which were just emerging from or still under colonial rule. This dependence also stemmed from the concentrated power and monopoly of technology that the "seven sisters" oil companies possessed on the world stage: their operations covered the full range of upstream and downstream oil production-from exploration and production, through transportation and refining, to marketing and retailing the finished products. ${ }^{2}$

Thus, during the greater part of the 1960s Nigeria played a passive rentcollecting role regarding its oil industry, making no moves to renegotiate contracts with MNCs, unlike its counterpart developing states of Algeria, Iraq, and Libya, which took unilateral action in abolishing concession agreements (Onyeji, 1990, p. 86). Even so, Nigeria did witness a swift rise in the government's revenue. This was a result of the growth in domestic oil production during the 1960s and from the higher royalty rates accruing from this oil. These revenues immediately became a bone of contention among the different regions of the newly independent state: under the federally legislated principle of derivation, the regions were entitled to the revenue generated in their own territory. Because Nigeria's oil is located in the southern part of the country, the North and West were gradually being excluded from the financial benefits of the oil boom.

As a result, the North and West formed an alliance to counter the Eastern region (which comprised the oil-rich South). This led to two military coups in 1966, the East's secession from the federation, and eventually to the 1967-70 Civil War, which claimed 2 million lives.

Although the fighting of the civil war had a great deal to do with the prospect of future oil wealth, ethnic differences and rivalries were incited in the process. As a result, Nigeria's oil boom, beginning in the early 1970s, came at a time when the state was concerned with the task of postwar reconstruction. The military leadership recognized that the reconstruction needed to be done in a regionally propitiative manner. 
Shortly before the cease-fire, the federal government enacted legislation whereby all revenues would accrue to the central government, to be divided proportionally among the states. At about the same time, the military government issued the Petroleum Decree of 1969, which replaced the Mineral Oils Ordinance of 1914. It was the country's first major attempt at producing a detailed and comprehensive law defining the rights and obligations of oil licensees. Significantly, it also vested the ownership and control of all petroleum interests in the central government. This decree was issued seven years after the UN had adopted Resolution 1803, which affirmed the principle of states' inalienable right to permanent sovereignty over their own natural resources. Although now generally accepted as a basic principle of international law, its passage was a major breakthrough for developing countries. At the time of the UN Resolution's passage in 1962, it empowered and gave confidence to newly independent countries all over the world to develop their resources as they saw fit and no doubt played a major role in the promulgation of Nigeria's 1969 Petroleum Decree. This decree signified an important (legal) step in the government's learning curve of how to do business with powerful foreign corporations.

Not long after this, in July 1971, Nigeria joined the Organization of Petroleum Exporting Countries (OPEC). Joining OPEC was a watershed moment in the development of the Nigerian oil industry. In fact, it would be difficult to overstate the importance of this membership's role in Nigeria's gaining of knowledge, control, and bargaining ability with regard to its oil industry. Nigeria was able to take advantage of other OPEC-member country experiences and guidelines and adopt laws already enacted by these countries. It also gave a tremendous boost to Nigeria's bargaining position within the international oil industry, as Nigeria began to negotiate for concessions and contractual particulars similar to those of other OPEC member states.

OPEC was formed in 1960 by major oil-producing developing countries as "an act of protest... a revolt against the highhandedness of the multinational oil companies" that had kept the price of oil "artificially low" (OPEC, 1984, p. 182). Events that led to the organization's founding included the oil companies unilaterally abrogating and then reducing the posted prices for Middle Eastern and Venezuelan oil, first in February 1959 and again in August 1960. This reduction of posted oil prices (which served as the basis for income under the existing royalty payment system) meant a sudden, unexpected reduction in revenues for the producer countries.

The shock suffered as a result of this unexpected and uncontrollable event, as well as the realization that oil prices had been kept artificially low by the multinationals, gave these countries a strong desire to take control over the price of their product, and thus over their domestic economies. It also provided a strong rationale for these countries to join in unity against the powerful MNCs.

The OPEC countries thus did "band together to form a highly effective bargaining unit in dealings with major oil companies" (U.S. Congress, 1973). Some of the resolutions the OPEC member countries agreed upon over the next decade were a 55 -percent tax rate for all member countries and an increase in the government's levy on each barrel of oil from 30 cents per barrel in 1970 to 65 cents per barrel in 1971. The member countries also agreed to raise the posted price-the price at 
which they would sell their oil on the world market-with subsequent price hikes to occur at regular intervals. They further moved to gain control over their oil industries and prices by controlling the amount of oil that would be produced within their borders.

Also significant regarding ownership for the oil-producing countries was the OPEC/Geneva agreement signed in 1972 that required member governments to own a 25-percent equity share in the foreign companies' operations. This rate was to be gradually increased to 51 percent by 1982, creating host country majority ownership in the MNC subsidiaries conducting business on their soil. Perhaps the most important OPEC requirement, at least as far as Nigeria was concerned, was the statute mandating the creation of a national, state-run oil company. The aim of this provision was for each country to learn how to run and control all aspects of its oil industry.

Article 90 of OPEC's Resolution XVI of 1968 enjoined member states to "seek participation in the equity of existing concessions" (OPEC, 1984), requiring Nigeria to acquire, by 1982, a majority participating interest in the oil company subsidiaries' operations within its borders. This stipulation, along with the collective knowledge provided by fellow OPEC member states of oil industry workings in such areas as pricing, taxation, and contract negotiations, provided Nigeria with both mandate and confidence to initiate negotiations and enter into new types of contracts with the oil MNCs.

The Nigerian National Oil Corporation (NNOC) was formed in 1971 to fulfill OPEC's membership requirements. It subsequently merged with the Oil Ministry to form the Nigerian National Petroleum Corporation (NNPC) in 1977. The NNPC is an agency of the federal government and exercises supervisory and regulatory control over the oil MNCs operating in Nigeria; it became the instrument through which the government was able to carry out OPEC's participation mandate. In 1972, the federal government vested all exploration and production rights in Nigerian territory in the NNPC, with the exception of those areas in which petroleum grants already existed (these would also become subject to renegotiation). Therefore, from this point in time, the NNPC conducted all contract negotiations with the MNCs. The NNPC was further empowered to prospect for, mine, and market oil and to engage in all other activities associated with the petroleum industry. This ultimately empowered it to monitor, supervise, and eventually run Nigeria's oil industry-in theory. The discussion of whether the NNPC has been successful in these endeavors will be taken up later. There is no denying, however, that the state's establishment of a national oil company played a central role in the expansion of Nigeria's role in its own oil industry and boosted its confidence and ability to negotiate one-on-one with the powerful MNCs.

Following the establishment of the NNPC, the success that Nigeria experienced in negotiations is most clearly illustrated by two notable developments. First, Nigeria followed the lead of other OPEC nations and entered into new forms of contracts with the oil multinationals. Second, it negotiated for a greater share of both profits and equity in existing and future contracts with the MNCs.

Before launching into a discussion of the negotiation advances Nigeria made at that time, it is important to add to this historical overview two important governmental edicts resulting from Nigeria's drive to increase participation in and control 
of its oil industry: the indigenization decrees of 1972 and 1979. In 1972, the military government again heeded ongoing domestic calls for economic nationalism by agreeing to the Nigerian Enterprises Promotion Decree, the first of the two Nigerian Indigenization Decrees. ${ }^{3}$ The promulgation of this act was also motivated by the drive to meet OPEC demands; the decree's strategy for action was control based on indigenous ownership and the need to use the oil industry as a vehicle for rapid economic development. The 1977 decree was an extension of the first decree, with further-reaching and more stringent regulations. It served to tighten up loopholes in the 1972 decree (Biersteker, 1980).

The decrees were intended to transfer a certain percentage of all foreign-owned businesses to Nigerian citizens; this included the multinational oil companies doing business in Nigeria. Other policies included dividing all foreign-owned economic activities into three categories and stipulating the level of equity sharing, which would be mandatory for each type of business, reserving certain areas for local capital. They further mandated that a certain percentage of Nigerians be employed at all levels of foreign-owned businesses. The policies were undertaken in order to reduce excessive foreign dependence and hasten the move to self-reliance in the oil industry.

The Indigenization Decrees were important development steps for Nigeria in setting the legal context for bargaining with the MNCs. We will return to a discussion of the effects-and effectiveness - of the decrees later. Next, let us examine the change in concession agreements once Nigeria commenced negotiations with the oil companies.

Starting in 1971, Nigeria began direct negotiations with the international oil companies through its newly created state-owned oil corporation, the NNPC. One of the goals of these negotiations was to increase equity participation to meet OPEC's mandate of, eventually, a 51-percent ownership interest in the MNCs' subsidiaries. One method for furthering this goal was to scrap traditional concession agreements and negotiate for (at the time) innovative agreements such as joint ventures, participation agreements, production-sharing agreements, and risk service contracts. All of these new types of contracts increased developing countries' participation rates and provided an avenue for the acquisition of petroleum technology and the training of Nigerians in said technology as well as in managerial and supervisory roles. The contracts spell out the legal relationship between the partners and lay down rules and procedures for the joint development of the areas concerned. ${ }^{4}$

The mere act of making such a specific, legally binding contract with each of the MNCs operating within its borders gave Nigeria a great deal of experience in terms of bargaining and doing business. Many aspects of these contracts were copied from those made in other OPEC countries-yet another instance in which Nigeria benefited from membership in the cartel and access to member countries' otherwise confidential information.

Another of Nigeria's goals for the renegotiation of contracts was a reduction in the duration of concession agreements. Nigeria was able to reduce terms of many agreements to a length of five years from 30 to 40 .

In 1971, the NNOC (later the NNPG) came to the bargaining table with the individual MNCs and requested a 35-percent ownership participation from each of 
them. In 1975, a round of renegotiations commenced, and the request was raised to 55 percent: in 1979, to 60 percent. Most companies signed agreements of assent to participation (at the 55-percent level) in 1974, and the policies became effective in the same year. Two holdout companies, Texaco and Standard Oil of California, finally agreed to the 55-percent level of Nigerian ownership in $1978 .^{5}$

The NNPC was also charged with the responsibility of awarding licenses and leases for oil development. The form that these new leases and licenses took, as well as the rights conferred and risks shared, were novel for Nigeria. These new agreements included the OELs, Oil Prospecting Licenses, and the Oil Mining Lease. The NNPC reserved the right of revocation in all of the above if the licensee or lessee was not conducting operations continuously or in a vigorous and businesslike manner, or otherwise failed to meet the conditions stipulated in the agreement.

In all of these measures, the changes in concessions and contracts reflected a fundamental shift in bargaining power between Nigeria and the MNCs. Nigeria commenced negotiations and successfully met its demands vis-à-vis the MNCs. There was also a marked increase in the government's revenue from the oil industry between 1971 and 1980 (Atsegbua, 1992, pp. 26-27).

\section{The Bargaining Game}

The game modeled here is an example of international bargaining, characterized by strategic decision making by each actor under conditions of uncertainty regarding the behavior of his or her counterpart, who, in turn, is trying to estimate the other's likely behavior-a two-player noncooperative bargaining game under incomplete information. Probabilities and beliefs are not given or fixed-they are subjective and subject to revision and recalculation. In this way, an opponent may reassess or readjust his strategy based on a refined perception of his counterpart's preferences through a revealed move. This possibility for readjustment in response to observed events characterizes Bayesian equilibrium analysis, which allows for the concept of learning during the bargaining process.

We assume, for the sake of simplicity, a world consisting of two actors: the MNC and the developing country (or state). We further assume that the developing country has little to no experience in bargaining, while the MNC's experience is extensive. In addition to bargaining experience, the MNC possesses intricate technical, logistical, business, and legal knowledge of all aspects of the oil industry. The developing country, on the other hand, does not possess such knowledge or experience.

Each player possesses knowledge of the outcomes of similar previous negotiations involving OPEC member countries and MNCs. In other words, both parties know that other developing countries have successfully negotiated outcomes similar to those that Nigeria is seeking. Furthermore, once the game between the state and one MNC has been executed, the other MNCs operating in that state will be aware of its outcome (and arguably more likely to agree to similar concessions).

Each square or node represents a choice for one of the actors; the actor making the choice is labeled below the square. There are two branches from each choice node, indicating the choices available to the actor. The choice of any circle-if 


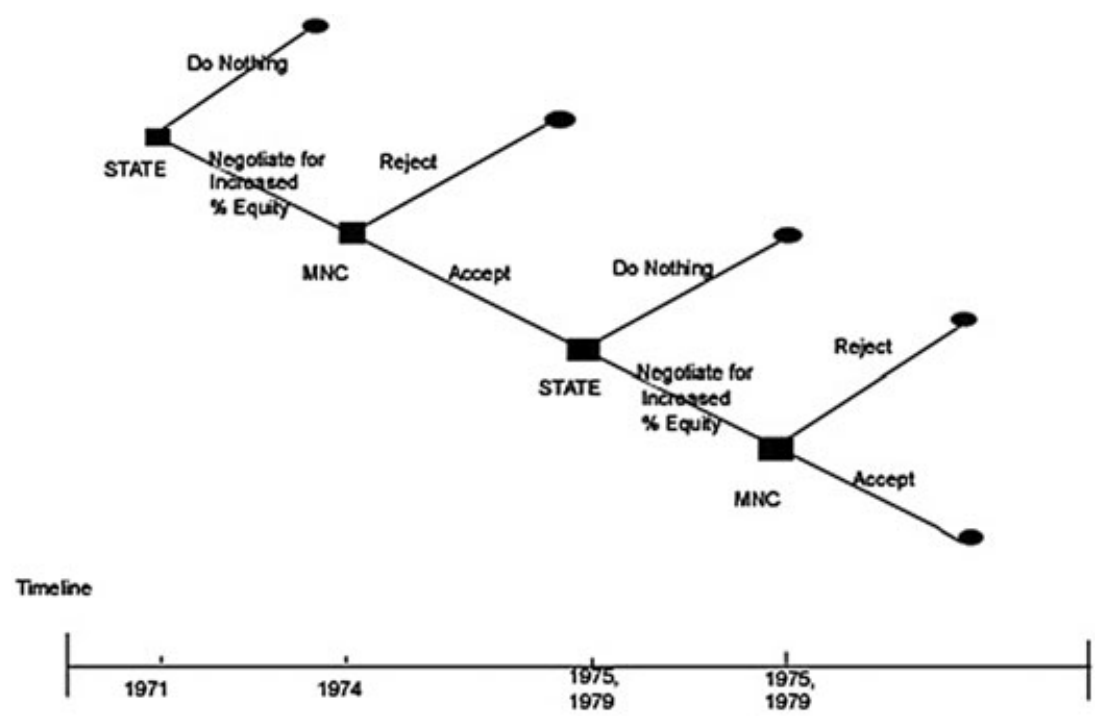

Figure 3. The MNC/LDC Bargaining Game for Nigeria.

MNC, multinational corporation; LDC, less developed country.

taken-represents an end to the game. A timeline below the game illustrates the real-time duration of the negotiations. An illustration of the game appears in Figure 3 .

This game is modeled on actual negotiations between Nigeria and the oil MNCs, beginning in 1971. As stated earlier, membership in OPEC spurred on these negotiations; the cartel required that by 1982 each member state possess at least a 51-percent equity (ownership) in all local subsidiaries of foreign-owned oil companies. In the earlier game, Player 1, the state, makes the first move. The state has two choices at this time: it can do nothing or it can negotiate for an increased percentage of equity/ownership in the subsidiary companies of the foreign-based oil MNCs.

If the state chooses the upper node and does nothing, the game is over the reader will recall that Nigeria made this decision on a number of occasions prior to 1971). If the state negotiates for an increase in equity from the MNCs, then the game continues to the second play, where the MNC (Player 2) takes its turn and has two choices (or moves): either to accept or reject the state's attempt to gain a percentage of equity in its subsidiary company. ${ }^{6}$ If the MNC rejects the state's negotiation attempt, the game ends (and we presume that this decision is an exit option-that the MNC pulls out of the state because it does not agree to the increasing demands that the state is making on foreign corporations. $)^{7}$ If, however, the MNC agrees to the state's proposed equity increase, the game continues. In fact, the second half of the game-illustrated in Figure 4-is simply a repetition of the first half as the state attempts, over time, to negotiate for an even greater percentage of equity/ownership in the subsidiary companies of the MNCs.

The numbers within the parentheses generally represent payoffs. (In this case, they correspond to the percentage equity ownership under negotiation.) The first number is the payoff (percentage) to the first player, the second to the second player-should the option(s) leading to that game-ending node be chosen. In this game, the parties negotiate over the division of an equity value of 100 , which the 


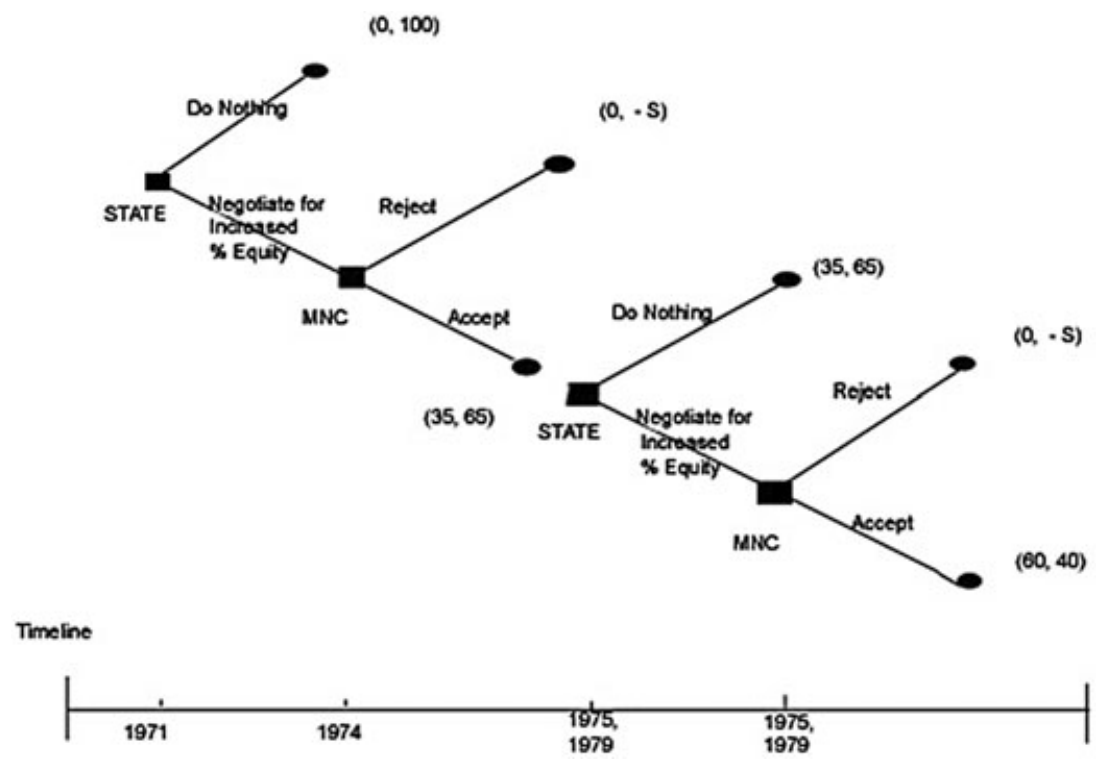

Figure 4. The MNC/LDC Bargaining Game for Nigeria with Payoffs. MNLC, multinational corporation.

MNC possesses in full at the commencement of the game. It should be borne in mind that these payoffs, like the game itself, represent extreme simplifications of a highly complex reality and serve as a tool to aid in understanding the bargaining process.

In the first payoff, where the state does nothing, the payoff is 0 for the state and 100 for the MNC, assuming that the state has 0 percent equity and the MNC has 100 percent equity in the subsidiary companies at the commencement of negotiations. As the rules for this game state earlier, if the state negotiates for an increase in equity of the MNC's subsidiary and the MNC rejects, the MNC ceases operations and pulls out of the state. The payoffs in this case are 0 for the state, and $-\mathrm{S}$ for the MNC, which represents the negative sunk costs (losses) the MNC faces for having made its investments and then ceasing operations and pulling out of the state. If, however, the state negotiates for an increase in equity in the MNC's subsidiary operations and the MNC agrees, the payoffs are 35 to the state and 65 to the MNC.

The second illustration also depicts a break in the game at this point. In fact, the game could end here and a new one be started once the state attempts to renegotiate for a higher equity share, with the payoffs reflecting what has transpired in the previous game. Should the state decide to do nothing, the payoffs will remain as the previous game ended-35 for the state and 65 for the MNC. If the state negotiates for an increased equity share and the MNC rejects this-keeping in mind that in our game this means that the MNC ceases operations and pulls out of the state- the payoffs are 0 for the state and $-\mathrm{S}$ (sunk costs) for the MNC. If, however, the state renegotiates for the increased equity share and the MNC accepts, the payoffs are 60 for the state and 40 for the MNC. Again, these numbers are meant to reflect actual Nigerian negotiation outcomes. If the state can succeed in arriving at the lowerright (South-East) game nodes, its payoffs have increased (from 0 to 35 in the first 
game and from 35 to 60 in the second game) and we can say that it has been successful in bargaining with the MNC.

As noted earlier, the game and payoffs mirror actual negotiations that took place between Nigeria (through the NNPC) and the petroleum multinationals from 1971 to $1979 .^{8}$ In 1971 the NNOC requested a 35 -percent level of equity participation from the MNCs' subsidiaries operating in Nigeria. By 1974 most companiesincluding Agip, Marathon, Texaco/Chevron, Phillips, and Mobil-had signed "agreements of assent to participation," which signified their acceptance of Nigeria's negotiated equity level. In 1975 the NNPC raised the equity level to 55 percent; in 1979 the level was again raised, to 60 percent. In both cases, the companies agreed to this negotiated level of higher equity for Nigeria. ${ }^{9}$ In terms of bargaining for increased equity ownership, we can conclude that Nigeria had (at least some degree of) success in the negotiations it undertook with the MNCs.

\section{Challenges to Nigeria's Success}

The case has now been made that Nigeria did, in fact, do better for itself over time in bargaining and doing business with foreign-based oil multinationals: it ascended its learning curve. However, Nigeria's is not an unabashed success story, and the argument will now be made that it could have done better in a number of areas. This section addresses the issue of Nigeria's ultimate failure to gain the technical capabilities necessary to run its oil industry-why the foreign-based MNCs still de facto run Nigeria's oil industry. It will argue that corruption played a determining role in the state's return of hard-won concessions to corporations, the repeal of indigenization laws, and the forcible deterring of growing levels of local participation in Nigeria's oil industry.

Most scholars of Nigeria agree that the state negotiated considerable advances vis-à-vis MNCs following its independence. It gained higher oil revenues, increased its level of equity participation, and decreased the length of contracts vis-à-vis the oil companies within its borders. In fact, it assumed a greater role overall in its domestic economic activities. However, as Biersteker (1980), who has done the most extensive work in this area, points out, an increase in the state's activities does not translate to greater effectiveness for the state, just as a simple increase in the level of equity in the oil industry does not equal an increase in the amount of control over that industry.

Let us return to the impact of the Nigerian Indigenization Decrees of 1972 and 1979. Domestically, the 1972 decree was initially hailed as a political and economic milestone for the government, a major step toward Nigeria taking control over its economy in general and over the oil industry in particular. And indeed at first, the indigenization decrees effectively functioned to benefit indigenous businesses and individuals. Yet because Nigeria did not come to possess the technological capabilities to run the complex oil industry over subsequent decades and because the corporations did not implement many portions of the decree, including the employment and training of Nigerians in their labor forces, the decrees eventually came to be seen more as empty promises, even as measures to rationalize the presence of foreign capital in the economy. Later, the military government would reverse its course and eliminate the advances the indigenous groups made. 
In order to ensure passage of the first decree, local businessmen joined forces and formed the Indigenous Businessmen's Group. This group lobbied government officials to endorse the decree. As a result of their efforts, the state initiated programs to encourage indigenous participation in the oil industry, requiring new oil concessions to Nigerianize not less than 60 percent of jobs at all levels and not less than 75 percent of management positions within ten years of obtaining their lease. Additionally, in 1970 the Central Bank of Nigeria introduced credit guidelines and stipulated minimum amounts of total lending for the commercial and merchant banks operating in the country; this was to target sectors of the economy (including the oil industry) and particular groups—notably indigenous private enterprise. To further assist local capitalists to get started in the industry, the NNPC organized indigenous individuals and small private companies to assist their entrepreneurial efforts to market Nigerian crude oil, beginning in late 1979. As a result of this encouragement by official powers, a number of local organizations-such as the Independent Petroleum Marketers Association of Nigeria-emerged.

This honeymoon between the government and private indigenous business was not to last, however. The growth of Nigeria's oil industry during the 1970s coincided with two world oil price surges and produced an unprecedented windfall of wealth for the country. Nigeria's spending and investment decisions in the late 1970 s proved unsustainable and ultimately left the state unprepared to face the subsequent world oil price crashes of the 1980s. As a result, Nigeria faced a painful economic recession during the 1980s that affected the country nearly as profoundly as the windfall had in the previous decade.

In December 1983, the army once again took power after allegations of massive governmental corruption, wasteful management of the economy, and mounting external debts in the face of declining revenues. The civil government was replaced, the short-lived Second Republic's constitution was suspended, and many of the indigenous advances made during the 1970s were stopped and shortly thereafter reversed.

Following the coup d'etat in 1983, state support for local capitalists began to disappear. The state took swift action to discourage further indigenous participation in the oil industry. One of the steps taken was to declare illegal the previously encouraged activities of indigenous groups, for example, the independent marketing and selling of oil. The state also revoked the rights of indigenous businessmen to make payments on credit while concurrently increasing the frequency and restricting the acceptable methods of payments required to continue operating in the oil industry. The multinational oil companies faced none of these restrictive actions.

The NNPC further edged out local companies by not renewing their contracts or by choosing foreign-based companies in competitive processes. By the end of 1985, the government had rather successfully curtailed indigenous participation in the oil industry. Of all the local private companies that had emerged in the encouraging atmosphere of the 1970s, only one survived by the early 1980s: the Nigus Petroleum Company. Its operations were restricted to the exploration stage only (Onyeji, 1990, pp. 104-5). It was denied permits to participate in all other areas of petroleum development even though it had applied for them. In fact, to give an example of the change in the state's priorities, in 1983, out of 13 permits 
issued by the NNPC to do exploratory work for future oil pipeline routes, 12 went to just four foreign oil companies. The single remaining permit was reserved for the NNPC. However, in the following year the NNPC turned this permit over to Shell BP because it did not possess the capabilities to carry out the survey operation itself. Clearly then, the government's reversal of its policy that originally encouraged local entrepreneurship played a key role in discouraging indigenous participation and limiting local control in Nigeria's oil industry. In addition, the state deterred locals from gaining employment or experience within the industry by not enforcing employment quotas stipulated for the MNCs by the Indigenization Decrees. This further hindered the country's stated desire to control its oil industry.

To make matters worse, in 1977, even as Nigeria negotiated for a higher level of equity in the MNC subsidiaries, it was taking counter measures to "sweeten the deal" for the MNCs by offering them a package of fiscal incentives that were unprecedented in their level of generosity. These included the following: The first was an exploration incentive, whereby the government agreed to pay for any unsuccessful wells. The second was a petroleum profit tax, which provided for the write-off of pre-production costs and further offered a reduced tax rate to the companies that allowed them to pay just 15 percent instead of the OPEC-standard rate of 85 percent. The third was a royalty incentive, which offered a lower rate of royalties than the going OPEC rate for oil found offshore, which is where large quantities of Nigerian crude had recently been discovered. The fourth was the investment tax credit, which encouraged and rewarded oil companies for making new investments in the country. This provided a tax bonus for any asset obtained for the purpose of petroleum operations in an amount equal to the investment. A fifth incentive offered that companies could recover their investments in five equal installments, in line with the trend in international oil markets (Onyeji, 1990, pp. 91-96).

In all of these incentives the state appears to be giving back to the oil companies the advances it made in the negotiations since bargaining had begun, just six years earlier. It is puzzling why Nigeria would consider such an incentive package to be in its best interest because no other OPEC countries did this either at that time or, indeed, at any time up to the present. In fact, by this time, many developing countries had "learned" the negotiation tactic of playing MNCs off each other to obtain further concessions (Singh, 2000, 2008). This was something Nigeria was perfectly positioned to do. The MNCs in Nigeria were not eager to leave the country: they had high-sunk costs and were already earning considerable profits from Nigeria's high-quality oil.

While Nigeria's motivation in offering this package to the corporations was, arguably, to encourage investment and exploration, in the long run it meant considerably lower earnings. As will be argued later, the overly generous incentives given to the MNCs were likely the result of a marked increase in corruption on the part of the Nigerian government and its representatives in the NNPC that altered the assumptions and perceived payoffs for the actors in negotiations. It is possible that those bargaining on behalf of the state came to believe that a short-term outcome that would benefit them (or those in power) on a personal level, combined with a negligible risk of being held accountable for such behavior, outweighed the 
importance of any longer-term considerations. We are not privy to the actual negotiations, yet backward induction may be employed to determine what players perceived as their optimal move(s). In this case, we know that government-level corruption reached unprecedented levels in Nigeria during the period from the late 1970 s through the mid-1980s, increasing through multiple, quick succession changes of leadership. This external shift in political realities may have, in turn, shifted the actors' assumptions and perceived payoffs. It would, in fact, be possible to formulate a new extensive form game based upon the observed outcomes from this new round of negotiations. However, it is beyond the scope and length limitations of this article to do so.

In terms of acquiring the skills necessary to increase participation in and control over the country's own oil industry, Biersteker (1987) argues that the MNCs figured out methods to retain de facto control over their subsidiaries, so that losing equity as a result of the negotiations was not a serious threat to either their operations or their profitability. Biersteker asserts that the MNCs have retained day-to-day control over the oil industry in Nigeria; in his interviews with senior executives of 23 of the largest MNCs operating in Nigeria, none expressed concern over loss of power because of Nigeria's increased equity participation. In fact, they have maintained effective managerial control regardless.

The MNCs have also retained their technical expertise by not training Nigerians, and in many cases they have managed to obtain exemptions from regulations not to their liking, as the state never enforced the few regulatory provisions that did make their way into negotiated agreements. Thus, Nigerians did not obtain skills in Moran's more advanced categories of knowledge: the operating and supervisory skills necessary to run their own oil industry and reduce dependence on foreign corporations.

The NNPC, in which so much hope was placed for taking control of Nigeria's oil industry, has also fallen short of expectations in a number of ways. Although it was intended to grow into an organization engaged in the entire spectrum of upstream and downstream oil development, it has remained almost a strictly administrative body, only marginally involved in the exploratory stage of oil development. While it saved for itself a number of the licenses it had the power to grant, it never used any of them (Onyeji, 1990, p. 118). Furthermore, as of the 1990s, the NNPC did not own any of the equipment or facilities used in oil operations; those that it uses, it rents from the MNCs. Even in the exploration arena, the NNPC depended on the MNCs for both equipment and technology. Similarly, the six port terminals used for the export of oil were built and remain owned by MNCs, while all the tankers that transport oil out of Nigeria are also foreign owned, and again the NNPC rents those that it uses. By renting all of the equipment and materials listed earlier, Nigeria actually pays multiple times over not only for the final product-refined oil, most of which it must import-but also for the very possibility of engaging in the operation of its own oil industry.

As of 2003, the government had been defaulting on its funding and payments to its joint venture partners - the MNC oil companies-for years. As these debts must be paid back with interest, the use of the term "joint venture" appears increasingly specious (Akinrele, 2003, emphasis added). During this time, and as a stated result of the NNPC's corruption levels, the government curtailed its access to funding. 
This hindered the NNPC's ability to cover payment arrears as well as the possibility of forming future joint ventures.

Additionally, Nigeria's oil refineries suffer intermittent shutdowns and are operating well below installed capacity. Resulting shortages have caused the country's heavy reliance on imported petroleum products, which has served to deplete foreign exchange earnings. This also means that continued subsidization of oil in Nigeria becomes increasingly expensive for the government, while threats to lift these subsidies result in riots, strikes, and other violent acts by the Nigerians. Because Nigerians know that the oil sector lies at the root of many of their problems, violence against the MNCs' property and employees has mushroomed over the years as well.

In addition to the above, there are still other challenges facing the NNPC. Nigeria is known for being an extremely corrupt country ${ }^{10}$; this corruption has affected the NNPC. In 1979, around the same time that the concessions were being given back to the MNCs, the NNPC was accused of "losing" 2.4 billion Naira from its accounts. This money was later discovered to be deposited in private accounts of NNPC employees at the British Midland Bank in London. An additional 12 billion Naira was reported missing through secret oil contracts involving third-party agents. Even when these contracts were considered legitimate, the contractual middlemen would regularly keep the NNPC's money in their own private accounts longer than agreed upon, taking advantage of Nigeria's rising inflation rates to make even more money on the sales (Onyeji, 1990, pp. 122-23).

Following closely upon the heels of the above, a Nigerian newspaper reported that 2.8 billion Naira was missing from the NNPC's coffers (Igweonwu, 1984, p. 272; Onyeji, 1990). As a result, in 1980 a Judicial Commission of Inquiry was set up to investigate these claims. Although the tribunal did not discover the whereabouts of the missing money, it reported other findings that contributed to the NNPC's record of scandals. One of these was that none of the service contracts executed between the NNPC and the operating companies had ever been signed and approved and were therefore still operating as "gentlemen's agreements." This situation was finally rectified in 1991 (Akinrele, 2003). Further, the tribunal reported that because of corrupt NNPC policies, such as those mentioned earlier, the government had lost 2.5 billion Naira in oil revenue, just from the years 1975 to 1978 (Onyeji, 1990). As a result of its findings, the tribunal proposed a fundamental reorganization of the NNPC including forming five wholly owned subsidiaries to carry out the various upstream and downstream oil industry functions, which the NNPC had not yet developed the capabilities to undertake in any case (Igweonwu, 1984). This restructuring was recommended to shift a great deal of authority away from the chief executive of the NNPC, who had up to that point wielded an inordinate "concentration of power" (Federal Republic of Nigeria, 1980). Financial control was also wrested from the NNPC, with the result that the NNPC now needs government approval for almost any significant financial decisions or investments (Akinrele, 2003).

Thus, evidence exists of the presence of the kind of corruption typically associated with negotiations over petroleum: secret deals that pad the bank accounts of those in the position to benefit from their closed-door, undisclosed 
nature. This type of corruption-basically bribery-is common to negotiations between representatives from developing countries and multinational oil corporations.

In contrast, the Nigerian government's decision to proactively wipe out what had up to then been increasingly successful local participation in the petroleum sector may also be attributable to corruption, but it most likely did not come about as a result of the negotiations with MNCs and was rather a policy taken by a government coming to embody a patronage system that prioritized the enrichment and entrenchment of its elites. This type of sabotage of previously existing local economic participation in the petroleum industry seems to be unique to Nigeria, and corporations do not generally bargain for this in their negotiations, as they generally realize that some level of indigenous participation in the petroleum sector is, in fact, in their best interests-it helps locals feel that they are benefiting from the presence of a petroleum industry. An absence of local participation in this industry can lead to local resentment-particularly if there is a lack of other employment opportunities in the area-and can, in the extreme, lead to violence against the MNCs if they come to be identified with the lack of economic opportunity or development, exactly as has become the case in Nigeria.

In both cases, therefore, the puzzling "unlearning" evidenced through the reversal of previous policies appears to be Nigeria's own doing, the result of increased levels of unchecked corruption and the related recalculation of self-interested, short-term strategies and not the result of the MNCs actually reasserting themselves and winning the upper hand through negotiations.

The silver lining to this otherwise unfortunate state of affairs is that Nigeria has demonstrated both learning and improved bargaining outcomes in the past. If the government is willing to recommit itself to the reduction of corruption and discontinuation of the elite-dominated patronage system and restore an emphasis on the development of its oil industry that takes a long-term perspective, progress and more favorable outcomes are possible. Further, the methodology presented here-a systemized use of game theory in which all assumptions are stated and strategies revealed-offers a procedure by which a developing country can refine its understanding of the game at hand, discover a way to do better for itself, and thus improve its negotiating skills.

\section{Conclusion}

This article applied Theodore Moran's dynamic bargaining theory-that developing countries do better for themselves over time as their experience with bargaining grows - to the specific case of Nigeria. It showed that game theory, and specifically Bayesian equilibrium analysis, can be a useful methodology for states to employ in this development interface, as it forces each player to take into consideration not just its own position but all the possible strategies and moves of its opponent before acting. Once a move has been made and a preference revealed, the player can adjust beliefs, recalculate expected probabilities and values, and better plan the next move.

A further argument for the use of such modeling of strategic interaction, particularly for developing countries, is that formal modeling forces a thorough 
analysis of the situation at hand. This obligates the player to state its knowledge, assumptions, and beliefs in entirety as well as its knowledge, beliefs, and assumptions about the other player at every potential stage of the game. Doing so may expose unstated information, reveal a gap in the knowledge about the game-or about the other player-and/or even lead to the realization of alternate moves or superior strategies. A complete knowledge of the game allows a player to act in a rational, consistent manner and, as in the game described earlier, to readjust beliefs as events change and eventually discover a way to do better for itself.

Although the previous section painted a rather dismal picture of Nigeria's ultimate ability to run its own oil industry, it is important to remember that the country did make advances on its bargaining learning curve, particularly during the 1960s and 1970s. As such, Nigeria's situation serves as a valuable case study. The game presented an example of Nigeria's success in bargaining, an ascension on its learning curve. However, it also would have been possible to construct a game analyzing the concessions Nigeria made to the oil companies in the form of the fiscal incentives package of 1977, a game in which Nigeria negated the negotiated ownership advances made during the same decade. In other words, Nigeria arguably descended the learning curve.

The factors contributing to Nigeria's stumbling blocks have been described earlier. According to Moran's theory, Nigeria-through both active and passive measures-failed to acquire two necessary components for eventual control of its oil industry: the supervisory and operational skills necessary to run such a technologically complex industry. This article further made the case that a precipitous rise in corruption may help explain the government's otherwise puzzling reversal of policies, beginning in the late 1970s, that ceased enforcement of successful programs, forced Nigerian entrepreneurs out of the market, gave back important advances through extremely generous concessions to the MNCs, and even repealed indigenization laws.

Yet this need not have been the case: other OPEC countries such as Algeria, Brazil, Venezuela, and Indonesia-none of which have been immune to corruption-have achieved success in the acquisition of the skills and technology necessary to run their own oil industries (Atsegbua, 1992). However, Nigeria's situation can change for the better: a serious governmental commitment either to seeing through the policies commenced in the 1970s or to setting forth a new set of policies that systematically promote indigenous development of the skills necessary to supervise, manage, and operate the oil industry would set Nigeria on a course toward an increase in its control over this industry. In the end, Nigeria's case provides a cautionary tale to the effect that without governmental commitment, early victories do not guarantee continued success: ascension on the bargaining learning curve is not a given.

\section{Notes}

1 See Vernon (1980). This concept was also thoroughly elaborated upon by Mikesell (1971, pp. 35-37) and touched upon by Penrose (1959) in her discussion of exploitation of host countries by the oil companies. However, the theory is generally attributed to Vernon. 
2 The major international oil companies widely known as the "seven sisters" were British Petroleum, Exxon, Gulf, Mobil, Royal Dutch/Shell, Standard Oil of California, and Texaco. See also Penrose (1971).

3 The state did not, in fact, initiate this decree. It reacted to pressures from indigenous local capital and large MNCs in finally agreeing to the decree. The final composition of the decree, as well as its results, reflect this collaboration. See Biersteker (1987).

4 Joint Ventures can include the following features: the Participation Agreement, which is negotiated on an individual basis and specifies the respective rights and duties of the parties; the Operating Agreement, spelling out the rules and procedure for the joint development of the areas concerned and the property jointly owned by the partners; and the Memorandum of Understanding, also signed on an individual basis, which commits the parties in the future to specified exploration, production, and work programs. There is further the Production Sharing Agreement, which, at the time that Nigeria signed its first (and only, for at least a decade) profit sharing agreement (PSA) in 1971 with Ashland Oil, was considered a novel type of agreement. In fact, Indonesia was the pioneer of this type of agreement, and Nigeria was extremely slow to adopt or negotiate for the PSA-and arguably far less successful in enforcing it.

5 These figures are given to provide an overview and are not comprehensive. For example, from 1979 to 1989, Nigeria held an 80-percent share of equity in the Shell/BP subsidiary. It is, however, beyond the scope of this chapter to go into much greater detail regarding all of Nigeria's equity agreements with the various MNCs.

6 This is a simplification for the purposes of keeping the game concise. In point of fact, the MNC could try to negotiate for a lower equity percentage to be transferred to the state, but this possibility alone would have resulted in virtually unlimited branches representing the choices available to the actors.

7 Biersteker (1980, p. 214) reports that only one of the hundreds of large, transnational corporations operating in the country has chosen an exit option and pulled out of Nigeria because of its increasing demands on foreign operations.

8 In fact, the game could be used to consider negotiations between a number of OPEC member states and foreign-based oil MNCs as these developing countries negotiated for (OPEC-mandated) increased equity shares of MNC subsidiaries within their borders.

9 These equity levels and the years mentioned earlier apply to the majority of MNCs in Nigeria but do not apply uniformly for all of them. To give an example, Texaco and Standard of California announced their final agreement on a 55-percent equity in 1978.

10 Transparency International has published an annual Global Corruption Report since 1999. In each year from 1999 to 2004, Nigeria ranked second from the last (meaning most corrupt) among all countries in the survey. In 2005, it moved up to tie for sixth from last place. Data and rankings are available at http://www.transparency.org. However, as of 2008, Nigeria had moved up significantly in these rankings, tied at 121 st place (out of 180).

\section{About the Author}

Laura Hosman is an Assistant Professor at Illinois Institute of Technology, in the Department of Social Sciences. She was recently a Ciriacy-Wantrup Postdoctoral Fellow in Natural Resource Economics and Political Economy at the University of California, Berkeley. Her work focuses on sustainable development issues, particularly in the areas of information and communications technology (ICT) and natural resources. Her work can be found in various disciplinary and multidisciplinary journals.

\section{References}

Akinrele, A. (2003). The Nigerian National Petroleum Company at a crossroads: An analysis of the challenges of funding, commercialization and autonomy. Oil, Gas \& Energy Law Intelligence, 1(2).

Asante, S. K. B. (1981). Transnational investment law and national development. Lagos: Lagos University Press.

Atsegbua, L. A. (1992). A critical appraisal of the modes of acquisition of oil rights in Nigeria. L.L.M. Thesis, University of Alberta.

Bates, R. H., Greif, A., Levi, M., Rosenthal, J. L., \& Weingast, B. R. (1998). Analytic narratives. Princeton, NJ: Princeton University Press. 
Biersteker, T. J. (1980). The illusion of state power: Transnational corporations and the neutralization of host-country legislation. Journal of Peace Research, 17(3), 207-221.

Biersteker, T. J. (1987). Multinationals, the state, and control of the Nigerian economy. Princeton, NJ: Princeton University Press.

Federal Republic of Nigeria. (1980). Views of the government of the federation on the report of the crude oil sales tribunal. Apapa: Federal Government Press.

Hosman, L. (2009). Dynamic bargaining and the prospects for learning in the petroleum industry: The case of Kazakhstan. Perspectives on Global Development and Technology, 8(1), 1-25.

Igweonwu, I. C. (1984). The politics of transformation: Nigeria, OPEC and the multinational corporations. PhD dissertation, University of Massachusetts.

McKern, B. (1993). Transnational corporations and the exploitation of natural resources. In P. Buckley, ed., Transnational corporations and world development (Vol. 10, pp. 1-36). London: International Thompson Business Press on behalf of the UNCTAD Division on Transnational Corporations and Investment.

Mikesell, R. (1971). Foreign investment in the petroleum and mineral industries: Cast studies of investor-host country relations. Washington, DC: Resources for the Future.

Moran, T. (1974). Multinational corporations and the politics of dependence: Copper in Chile. Princeton, NJ: Princeton University Press.

Morrow, J. (1994). Game theory for political scientists. Princeton, NJ: Princeton University Press.

Odell, J. (2001). Case study methods in international political economy. International Studies Perspectives, 2(2), $161-176$.

Onyeji, B. C. (1990). The postcolonial state and industrialization: The state and the oil industry in Nigeria. PhD dissertation, University of Denver.

OPEC. (1984). OPEC Official resolutions and press releases 1960-83. Oxford: Pergamon Press.

Penrose, E. (1959). Profit sharing between producing countries and oil companies in the Middle East. Economic Journal, 69(274), 238-254.

Penrose, E. (1971). The growth of firms, Middle East oil and other essays. London: Frank Cass \& Co.

Singh, J. P. (2000). Weak powers and globalism: The impact of plurality on weak-strong negotiations in the international economy. International Negotiation, 5, 449-484.

Singh, J. P. (2008). Negotiation and the global information economy. Cambridge: Cambridge University Press.

Smith, D. N., \& Wells, D. Jr. (1975). Mineral agreements in developing countries: Structures and substance. The American Journal of International Law, 69(3), 560-590.

United Nations. (1982). Main features and trends in petroleum and mining agreements: A technical paper. New York: United Nations.

U.S. Congress (1973). Hearing before the Subcommittee on Foreign Economic Policy. "Oil negotiations, OPEC and the Stability of Supply," 93rd Congress, 1st Session. April 10. Washington, DC: U.S. Government Printing Office.

Vernon, R. (1971). Sovereignty at bay: The multinational spread of U.S. enterprises. New York: Basic Books.

Vernon, R. (1980). The obsolescing bargain: A key factor in political risk. In M. C. Winchester (Ed.), The international essays for business decision makers (pp. 281-286). Houston: The Center for International Business. 